\title{
Constitutional conflicts in the European Union: Court packing in Poland versus the United States ${ }^{1}$
}

\author{
Richard J. Sweeney ${ }^{2}$
}

\begin{abstract}
-When the legislative and executive powers are united in the same person, or in the same body of magistrates, there can be no liberty; because apprehensions may arise, lest the same monarch or senate should enact tyrannical laws, to execute them in a tyrannical manner.

-There is as yet no liberty if the power of judging be not separated from legislative power and the executive power.
\end{abstract}

De L'Esprit des Lois [The Spirit of the Laws] (1748) Charles-Louis de Secondat, Baron de La Brède et de Montesquieu

\begin{abstract}
Court packing greatly threatens democracy. This paper examines, compares and draws conclusions from two attempts: The PiS government is near to packing Polish courts; President Roosevelt tried but failed to pack the U.S. Supreme Court in 1937. In most democracies a head of government with a legislative majority and strong party control can pack courts, giving complete control. The United States escaped; Roosevelt lacked complete party control. Poland is unlucky; PiS is strongly controlled. Peaceful domestic protest is necessary, but Poland's hope is from EU-level institutional pressure, supported by major democracies, to reverse packing and prevent further seizure of power.
\end{abstract}

Keywords: Poland, constitutional law, constitutional court, constitutional rights, Supreme Court Compliance, judiciary, court packing, European Union, United States.

JEL codes: K0, K1, K100.

\footnotetext{
${ }^{1}$ Article received 1 August 2018, accepted 24 September 2018.

Sweeney thanks Michal R. Belknap, Tadeusz Kowalski, Clas Wihlborg, and two anonymous referees for helpful discussions and comments.

In considering American and Polish freedom, 'dulce et decorum est' to recall two Poles, among many, who fought for American independence: Tadeusz Kościuszko and Kazimierz Pułaski, famous still in American memory.

${ }^{2}$ McDonough School of Business, Georgetown University, U.S.A., Claremont Institute for Economic Policy Studies, Claremont Graduate University, U.S.A. and University West, Sweden, sweeneyr@georgetown.edu.
} 


\section{Introduction}

Court packing greatly threatens democracy. This paper examines, compares and draws conclusions from two attempts: The PiS government is near to packing Polish courts; President Roosevelt tried but failed to pack the U.S. Supreme Court in 1937. In fighting court packing, peaceful domestic protest is necessary, but Poland's hope is from EU-level institutional pressure, supported by major democracies, to reverse packing and prevent further seizure of power.

Almost any liberal theory of representative democracy envisions "rotation of power" among different governments in a country. In any representative democracy, when a new government defeats the incumbent, the victor moves to take control of the executive, legislative and judicial branches, to replace the old government's appointees with their own. Supporters of the old government, burrowed into the bureaucracy, can greatly slow or in some cases completely hinder the new government's policies. The number of replacements in each of the three branches, and how replacements are made, depends on the country's constitution, laws and customs. A key distinction is between "permanent" civil service appointees and "political" appointees, though again exact meanings greatly differ across countries. In the United States the total number of federal civil servants was approximately 2.19 million at the start of 2012 (plus approximately 600,000 Postal Service workers), and the number of political appointees is over $7,000,{ }^{3}$ or approximately 0.32 of one percent of federal workers. Among these are powerful jobs, such as Secretaries of State and Defense, down to relatively low level secretaries.

A new U.S. president, however, can replace no sitting judge. In the United States federal judges are appointed "for good behavior," that is, for life-conditional on good behavior. Polish judges on the Constitutional Tribunal and the Supreme Court, in contrast, are appointed for fixed terms of service, under various conditions (see below). In both countries a new government eventually gets to appoint new judges. U.S. federal judges retire or die; Polish judges retire, die or their terms end. Sometimes chance lets a government fill many judicial vacancies soon after it takes power. Sometimes a government must let time and nature take their course.

Sometimes a government is in too big a hurry to wait to bend the judiciary to its will. When a hurrying government oversteps normal bounds this may signal bad intentions. Of course, court-packing means the government wants to appoint judges who will approve of new legislation that previous judges would not. The big fear is that the government will push through legislation to cement

\footnotetext{
${ }^{3}$ See the "Plum Book." Over 7,000 federal civil service leadership and support positions in the federal government, nationwide, are subject to non-competitive appointments, called political appointments.
} 
its hold on power. The government may choose among an infinity of ways to bias future elections in its favor against competing parties.

This paper compares two cases of court packing. The earlier is that of U.S. President Franklin D. Roosevelt, a liberal Democrat, in 1937. Roosevelt failed embarrassingly. The other is the attempt by the Law and Justice Party (Prawo i Sprawiedliwość, PiS) after its victory in the 2015 parliamentary elections. In contrast to Roosevelt's embarrassing failure the PiS has largely succeeded. Both of these court-packing attempts led to constitutional crises.

There are many ways to analyze these constitutional crises. This paper relies on international comparison. First, it compares the Polish and U.S. constitutions relative to court packing. The U.S. Congress does not choose the head of government and the U.S. president frequently does not have party control over Congress. The Polish parliament chooses its head of government; with tight party control, as under PiS, the Polish executive and legislative branches may essentially move as one. Second, relative to court packing, this paper also compares Poland's situation in the European Union to that of an individual state in the American federal union: Supremacy of federal Constitution and laws over state constitutions and laws, is long and well established in the United States, but not so much in the European Union.

To be sure, U.S. institutions and approaches and the U.S. Constitution are not benchmarks for EU institutions and its member states. (For example, U.S. political and constitutional failures led to the Civil War, 1861-1865.) Rather, comparisons help to reveal constitutional approaches that may help to avoid crises and show the limitations of relying on documents to preserve member states and the European Union from constitutional crises.

Court packing shocks many observers, but it has huge, tempting advantages. First, while the court-packing government is in control the tame court will not overturn its legislation. Second, it can hope that the packed court will impose constitutional changes that the government would find it hard to achieve through legislation. For example, whatever one's personal opinion on the substance, the probability was minute that the U.S. Congress would ever impose country-wide abortion rights, as the Supreme Court did in 1973 (Roe v. Wade), or country-wide legalization of same sex marriage. [Section III discusses other questionable Supreme Court decisions.] Third, if the country remains democratic, eventually the court-packing government loses power; the packed court may prevent later governments from reversing the previous government's changes. Fourth-most ominously_control of the Court may allow the incumbent government to adopt policies to keep it in office indefinitely. A government that thinks its policies so important as to justify court packing may think it is too dangerous ever to give up power.

This Paper's Bias. This paper views court packing as dangerous to a free, democratic, republican government, including PiS's attempts to seize judicial power in Poland. It seems the PiS government came to power constitutional- 
ly and is using methods that arguably give their opponents little recourse under Poland's constitution. This paper analyses the Polish constitution and EU Lisbon Treaty to show how PiS has gotten so far. Frustrated at home, Polish opponents have turned to EU institutions, which have in turn confronted the PiS government. This paper analyzes how the European Union, under the Lisbon Treaty, ${ }^{4}$ might stop PiS and thus prevent grave damage to Poland and indeed the European Union.

This paper's bias against PiS's court packing is clear. But its analysis of EU, Polish and U.S. institutions aims to be unbiased. Pretending neutrality about court-packing would be dishonest and would undermine the integrity of the analysis.

In what follows the paper examines in Section 1 whether constitutions can prevent court-packing crises. Section 2 examines the court-packing cases in the United States in 1937 and the current PiS court-packing. Section 3 then turns to what the U.S. government might do if one of its states packs its courts and what E.U. institutions might do about PiS court packing.

\section{Can constitutions prevent court-packing crises?}

There is no use in pointing fingers about how things go wrong. It is highly useful, however, to review constitutional flaws in the hope of correcting them in the future or to allow countries to learn from others' errors.

Accession to the European Union. Could the European Union have forestalled this crisis by requiring Poland before accession to revise its constitution to prevent such problems? Any candidate for admission to the European Union goes through a long, contentious process before acceptance: see the "Accession criteria (Copenhagen criteria)." The European Union demands many changes in the candidate's constitutions, laws, and institutions, as well as complete acceptance of the EU acquis communautaire. Perhaps EU negotiators are not demanding enough. For example, they push for reforms designed to reduce corruption in government and the courts, but often new members still have disturbing amounts of corruption. Sadly, corruption appears not to die off over time (consider some long-time EU member states).

It appears the European Union fails to require member states to adopt constitutions that would likely prevent evolution that the European Union as a whole cannot tolerate, as substantially violating EU values, for example Hungary and Poland. Such requirements might seem unfair because they would substitute the

\footnotetext{
${ }^{4}$ The Lisbon Treaty (approved 2007, in effect 2009) is a modestly changed version of the proposed EU constitution, defeated in The Netherlands and France in 2005 and subsequently withdrawn. Formally, the European Union has no constitution; the Lisbon Treaty approximates one.
} 
opinions of current EU member states (and politicians) for the candidate-state citizens. Nevertheless, well designed requirements, accepted before membership by the candidate states, might obviate possible battles between the newer states and the EU Commission or the majority of EU members (especially dangerous if including the powerful Germany and France). But how feasible is this?

Range of EU Member-State Constitutions. Can pre-admission vetting stave off later constitutional conflicts between EU institutions and memberstate governments? EU member states have great variety in their constitutions, ranging from the "Westminster" system in the United Kingdom, ${ }^{5}$ to the hybrid presidential-parliamentary system in France, with a relatively strong president. The United Kingdom uses a first-past-the-post system for all geographical-district seats in the House of Commons-the candidate with the plurality wins. Willy-nilly this system tends to produce two major parties that dominate much of the time. ${ }^{6}$ In French presidential elections the first round winnows several candidates down to the two strongest, who then have a run-off two weeks later. French politicians are proud that this system sees to it that if an "extremist" gets through to the run-off, opponents of "extremism" will unite to elect the more moderate candidate (for example, Chirac in 2002 and Macron in 2017). It would take great effort and deep insight to review EU member-state constitutions to identify provisions that should be changed because they might later allow developments that EU institutions and member states think unconstitutional under EU law, or even just unacceptable. It seems reasonable to require changes in constitutional provisions that pretty obviously are risky, but pushing too far into speculation about possibilities likely generates little improvement but deep and lingering bad feelings.

How PiS won under the Polish Constitution. Those who are startled and appalled that PiS won power in Poland through fair and free elections sometimes note that it received only 37.58 percent of the vote and the percentage of eligible voters who turned out was relatively low. Nevertheless, the PiS won sufficient seats to pass laws designed to cement its power and try to give it more power: 235 out of 460 seats (51.09\%) in the Sejm (parliament), 61 out of 100 seats in the Senat. Sejm elections use open ${ }^{7}$ party-list proportional representation in multi-seat constituencies [with the method called Jefferson (in the United States) or D'Hondt (in Europe)]. The threshold is generally 5\% for

\footnotetext{
${ }^{5}$ Yes: soon to be gone from the European Union, but particularly interesting.

${ }^{6}$ So it seems from reviewing English, British, and UK history, and also U.S. history; still, a small sample. First-past-the-post goes back to at least the 13th century in England. It was adopted by American colonies and then the United States. The method gives constituents a name and face to which to complain, rather than a nameless party apparat. Further, elected members can build power independent of party.

${ }^{7}$ In an open list voters' choices determine the order; in a closed list the party does.
} 
single parties, $8 \%$ for coalitions. Senat elections, however, are first-past-the-post in single-member districts. ${ }^{8}$

As noted, PiS received 37.58 percent of the votes cast. 15.93 percent, however, went to parties or coalitions that fell short of thresholds to win seats. Of votes cast for seat-winning parties, 44.7 percent went to PiS-still less than the 51.09 percent of seats PiS won. ${ }^{9}$ Obviously, if the thresholds had been low enough, PiS would not have won 50+ percent of seats. But thresholds serve many valid purposes. With sufficiently low thresholds, disgraceful parties may slip into parliament, ${ }^{10}$ possibly causing all sorts of problems, for example, keeping mainstream-party coalitions from governing.

Designing a Constitution to Protect the Constitutional Order. One way a constitution can restrict bad behavior-slow it down, perhaps prevent it-is to mandate clear and explicit separation of powers among the legislative, executive, and judicial branches, as does the U.S. Constitution. ${ }^{11}$ (Note that the Polish constitution requires an independent judiciary.) But simply mandating separation of powers is far from sufficient. In a proper modern democracy every branch must also face the threat of being held accountable by the voters or by the other branches, preferably both. In the United States members of the House of Representatives must face voters every two years and Senate members every six years, one third of them every two years. The president can veto any law Congress makes, but Congress can override the veto by a two-thirds vote in each house. If the president has behaved sufficiently badly the House can impeach him/her by majority vote and the Senate then tries the president, requiring a two-thirds vote for conviction and thus removal from office. Any officer of the U.S. government is also subject to impeachment under the same conditions, including federal judges, even Supreme Court justices. The House has impeached two sitting presidents, Andrew Johnson and Bill Clinton; only Richard Nixon's resignation saved him from impeachment. The Senate convicted neither Johnson nor Clinton. Fifteen federal judges have been impeached, eight convicted, ("Impeachment of Federal Judges", n.d.) and one cabinet member was impeached but not convicted. ${ }^{12}$ Conviction strips the accused of office.

${ }^{8}$ Sejm and Senat candidates must collect signatures to get on the ballot. Requirements for signatures etc. are somewhat different for national minorities.

${ }^{9}$ Amending the constitution requires a two-thirds super-majority, 307 Sejm deputies, not the 235 of 460 seats PiS won. PiS's constitutional dominance comes from methods such as court packing not amendments.

${ }^{10}$ First-past-the-post systems in geographical districts, as in the UK and U.S., serve a similar function.

${ }^{11}$ Note: The Constitution never uses the phrase, "separation of powers."

${ }^{12}$ William W. Belknap was the 30th U.S. Secretary of War. The House impeached and the Senate tried him; a majority, but less than two thirds, voted to convict, thus acquitting him. [Mikal R. Belknap, a chair-holding professor of law and a distinguished historian, a long-time friend of the author, is related to William W. Belknap.] 
Regarding the United Kingdom a short but not so misleading view is that the constitution is exactly what Parliament, in particular the House of Commons, says it is. If the prime minister and his/her government has a large majority and strong control over party members, the constitution is what the government says it is. If the Commons wants, it can overcome any opposition in the Lords or the UK Supreme Court by altering these institutions' powers, even abolishing them. The United Kingdom allows the greatest potential power to parliament of perhaps any parliamentary system. If the prime minister dominates the Commons there is no gap between the government and the legislature. Of course, traditions and possibilities of intra-party revolutions or voters' revulsion restrict what even a very strong UK government might try. Tony Blair's first government had a 179 seat majority out of 650 , his second 166 , this third 66. Blair made many changes during his approximately 10 years in power, but seemed careful to avoid changes widely viewed as unconstitutional.

In Poland today the situation is very close to the worst case scenario of what could happen in the United Kingdom. The PiS government has majorities in both the Sejm and the Senat and exercises very strong party discipline over its legislators. Further, the PiS is on the brink of so packing the Polish courts that judicial constraints are gone.

\section{Packing the Court}

All federal judges, including U.S. Supreme Court justices, are appointed during their good behavior-put another way, for life, conditional on good behavior. The Constitution provides that Congress can review judges' good behavior by the impeachment process (U.S Const., art. III, $\$ 1$ ) ${ }^{13}$ Impeachment is a high standard that protects judges' independence, conviction is an even higher standard. Court packing, however, is another, extra-constitutional way of attacking judges' independence.

U.S. presidents have tried court packing in three important episodes, the most serious under President Franklin D. Roosevelt. ${ }^{14}$ Roosevelt (president, 1933-1945), took great offense that the Supreme Court found unconstitutional

${ }^{13}$ Sparsity of detail is typical of the Constitution. Historical reasons for this sparsity with regards to courts is discussed below in text and footnotes.

${ }^{14}$ Before Roosevelt the United States faced two other instances of court packing. In the Marbury v. Madison fight, from 1800 to 1803, the Federalists tried court packing (increasing the number of judges and filling the seats) after they lost the 1800 elections. Victorious Democratic Republicans responded by their own successful (reverse) court-packing (reducing the number of judges, throwing out those the Federalists had appointed). The Federalists also created some minor magistracies and one of these led to the important Supreme Court case Marbury v. Madison (1803); the Court decided it had no power to overrule Democratic-Republican court-packing attempts. 
many of his economic laws during his first administration (1933-1937). On the one hand Roosevelt had no strong beliefs that any of the rejected laws were key to rescuing his country from the Great Depression. ${ }^{15}$ On the other hand he had to have expected to make Court appointments in his second term-he would have more chance to get legislation past the Court. But in the fall of 1933, in office only half a year, Roosevelt was already thinking of ways to bend federal courts to his will, the whole system, not just the Supreme Court. He ordered a task force to find ways (Leuchtenburg, 1995; McKenna, 2002; White, 2000). In late 1936 Roosevelt and his team hit on the court-packing plan. After his landslide electoral victory in November, 1936, Roosevelt proposed the Judicial Procedures Reform Bill of 1937 to add justices to the Supreme Court. As president he would appoint the new justices, surely ones he believed would support his legislation and the Democratic Senate would approve them. The key was that the president could appoint another justice every time a justice turned 70 years plus 6 months. Since 1869 the Supreme Court had had a chief justice and 8 associate justices. The bill would have allowed the number to expand to a maximum of 15 . Voters were close to evenly split, $47-53 \%$ for the bill, Democrats 70-30\%, Republicans 8-92\% (Saad, 2016). Though some people are surprised in the second decade of twenty-first century, many Democratic politicians were conservative in the 1930s and many important Democrats in Congress, along with a large proportion of Republican members, opposed what they viewed as an unconstitutional, dangerous power grab. ${ }^{16}$ Congress easily killed Roosevelt's bill. ${ }^{17}$ This attempt left court packing in bad odor.

Roosevelt and his advisers wanted to make sure that their economic and social programs got through the Supreme Court. They also wanted to retain power, not only for their party but for themselves. In 1937 Roosevelt may have

As the Civil War ended the Republican President Abraham Lincoln was murdered; Vice President Andrew Johnson succeeded him. Johnson was not a Republican but a "War Democrat," who behaved in office largely as a Democrat. Majorities in both the House and Senate were strongly Republican, dominated by "Radical Republicans." The House impeached Johnson; the Senate fell short of the two-thirds majority for conviction. Congress and Johnson battled until his term end in 1869. To prevent him from filling Supreme Court seats that became vacant Congress reduced the number of seats, done over time as a justice retired or died. When Johnson's term ended in 1869 Congress set the number of justices to nine, where it has since remained.

${ }^{15}$ American liberals' main description/justification of Roosevelt's programs was as "experiments" (Schlesinger, 2003a, 2003b): he would boldly try various programs until he found what worked. This view saves Roosevelt from the obloquy of supporting intellectually programs that were counterproductive or did not work.

${ }^{16}$ Roosevelt's vice president opposed the bill. As an example of arguments, see Wheeler (1937).

${ }^{17}$ It is not clear that the United States would now be so lucky as in 1937 when Roosevelt's control over Democrats was not strong enough to force through court packing. The Congressional Republican party is split internally, with some factions, for example, the Freedom Caucus, highly unlikely to support court packing no matter what leaders say. Democrats in Congress have become increasingly unified behind their leaders. 
been looking forward to perhaps his greatest innovation: He ran for both a third and then a fourth consecutive term, breaking precedent set by Washington, Jefferson, Madison and Monroe, Founders who thought two terms enough for anyone. In 1940 Roosevelt argued that war in Europe justified his third term. But if Roosevelt had a precedent-shattering third term in mind in 1937 he could not have counted on the Second World War in Europe and Asia to boost his candidacy. A compliant Court, however, supporting his legislation, would smooth his way. Suspicions of possible abuse by Roosevelt or any president largely explained much of the opposition to court packing.

Roosevelt's political defeat stung but the Supreme Court soon became much more accommodating to his many proposals that had far-reaching, long-lasting effects on the economy, society and law. ${ }^{18}$ The court explicitly switched to applying strict scrutiny to laws affecting personal liberties, as protected in the Bill of Rights, but to applying substantially less rigorous scrutiny to laws affecting property rights. ${ }^{19}$ The Supreme Court went from often strenuous defense of economic rights and the right to contract to showing these rights little deference. ${ }^{20} \mathrm{~A}$ large body of literature discusses the extent to which the substantial

${ }^{18}$ When Roosevelt's successor, Harry S. Truman (1945-1953) left office in 1953 every justice had been appointed by a Democrat. Legitimate court packing, through winning many elections.

${ }^{19}$ Many eighteenth-century liberal formulations identified the rights to "life, liberty, and property." In the late nineteenth and early twentieth centuries many Americans identified rights that deserved constitutional protection as those in the Bill of Rights (the first ten amendments to the Constitution). Though not explicitly mentioned in the Bill of Rights many thought that prominent among their rights were rights to their property and their liberty to contract. The Supreme Court relied on "liberty to contract" to overrule restrictions such as state minimum wage and labor laws. The counterargument was that states had police powers to legislate regulations to protect health, safety, morals, the well-being of children and women and more. Some Supreme Court cases acknowledged the conflict, but argued that in balancing the individual's right to make contracts they wanted with the states protective powers under police powers, the burden was on the state to show that the regulations served an important state interest and were in fact saving individuals from harm. Over time the Court went back and forth on economic rights and the right to contract. Some police-power regulations were acceptable, some not, the boundaries unclear.

With United States v. Carolene Products Company (1938), the Supreme Court definitively reversed direction on economic liberty and the right to contract. The Court held that the federal economic regulation at issue was "presumptively constitutional," and thus Congress had presumptive legislative discretion. Because substantial public-health evidence (later shown to be valueless) supported the law, the law was not arbitrary or irrational. Without saying so, the Court used what became the "rational basis" test.

${ }^{20}$ Carlene contains the famous footnote four:

There may be narrower scope for operation of the presumption of constitutionality when legislation appears on its face to be within a specific prohibition of the Constitution, such as those of the first ten amendments, which are deemed equally specific when held to be embraced within the Fourteenth...

Thus began the strong tendency for the Supreme Court to show "strict scrutiny" to certain favored rights (such as some explicit in the Bill of Rights), but to apply the almost toothless stan- 
change in Court behavior was the result of Roosevelt's court-packing threat. Any system is at risk if it allows alteration of the number and composition of courts' members simply by legislation, as in the United States and Poland, as opposed to requiring difficult constitutional amendment. Serious threats of court packing may cow courts. In the end the Court became more subservient on Roosevelt's issues than perhaps even he had planned.

Roosevelt's humiliating defeat in 1937 discredited court packing for decades. The possibility of court packing, however, has seen a resurgence since 2017-2018. On the one hand proposals by right-leaning scholars Calabresi and Hirji $(2017,2018)$ called for large expansion of federal courts below the Supreme Court; these proposals surprised, even shocked, many conservative and libertarian constitutional scholars (Calabresi 2017; Somin 2018), who greatly respect institutions. Calabresi and Hirji's argument turns largely on the "need" for more federal judges below the Supreme Court, but they make it clear that the court-packing aspect has its charms. On the left many argue explicitly for court packing for political ends (Carter, 2018; Goodman, 2018; Lemieux, 2018; Lithwick, 2017; Tushnet, 2017; Millhiser, 2015). A number of scholars, mostly to the right, responded to Calabresi and Hirji and also to arguments on the left (Blackman, 2017; Primus, 2017; Somin, 2017; Yoo \& Delahunty, 2018).

The U.S.s Situation When Writing the Constitution of $1789 .{ }^{21}$ How "tight" should restrictions be on the changes to the judicial system? This question requires historical context.

The Framers left much about the judiciary for Congress to fill in for several reasons. ${ }^{22} \mathrm{~A}$ main reason was that the men at the Constitutional Convention knew that there would be great changes in the United States within a few decades and unknowable changes over longer time. It was clear that Kentucky would break off from Virginia and become a new state; similarly, Tennessee would break off from North Carolina and become a new state. Vermont's conflict with New York would very likely end with Vermont entering the Union. The Founders thought the Northwest Territory would gain huge numbers of immigrants and likely the Southwest Territory would gain even more and both would add states to the union. ${ }^{23}$ Many people at the time believed, with more

dard of "rational basis" to issues that involve economic rights or liberty of contract. Under rational basis the Court can rule against the government only if there is no possible set of circumstances in which the regulation is rational. The individual has little hope of prevailing against state or federal economic legislation. To be sure, there is a huge amount of literature on these tests.

${ }^{21}$ The Constitution was written in 1787 and went into effect in 1789.

${ }^{22}$ The U.S. Constitution specifies the establishment of a Supreme Court. See footnote 12 above.

${ }^{23}$ Together these territories were roughly the area between the Appalachian Mountains and the Mississippi River. The Northwest Territory was north of the Ohio River up to the Great Lakes, the Southwest Territory below the Ohio River to the Gulf of Mexico or Spanish territory. 
or less strength, that one day the United States would extend to the Pacific Ocean. No one foresaw the Louisiana Purchase of 1803, adding a huge territory west of the Mississippi, or the Adams-Onís treaty of 1819 that added Florida and settled the border between New Spain and the United States (thus settling the boundaries of the Louisiana Purchase), or the annexation of Texas in 1845, the agreement over the Oregon Territory with Great Britain in 1846 and the results of the Mexican War (1846-1848) that added much of the remainder of what is now the United States. ${ }^{24}$ How many federal district judges would be required to preside at trials, and where and when; and how many appeals' courts for these federal trials would be required, at the intermediate level, before appeals went to the Supreme Court? The Framers left this to Congress, surely wisely. In fact, originally, Congress created only district courts for initial trials in 1789, with appeals direct to the Supreme Court-no intermediate level of appeals. $^{25}$

Poland's Situation When Writing the Constitution of 1997. Poland was in a very different geographical/population situation when it wrote its 1997 constitution (The Constitution of the Republic of Poland of April 2, 1997) that replaced the constitution that had been amended after the communist dictatorship. It need not have left so much for the Sejm to decide regarding courts. The 1997 constitution might easily have included more provisions to limit court packing. ${ }^{26}$ Still, a leader strongly controlling both the executive and legislature would likely find a way.

${ }^{24}$ Remaining were the Gadsden Purchase and other minor treaties to give today's contiguous, continental United States. Also remaining were the purchase of Alaska (1867) from Russia and the annexation of Hawaii (1898). The Spanish War (1898) led to U.S. annexation of Puerto Rico and Guam, temporary possession of Cuba (independent 1902) and The Philippines (independent 1946). It also gained possession of some small territories; were any of these territories, not of strategic importance, to desire independence, they surely would be let go.

${ }^{25}$ The United States courts of appeals (circuit courts) are the intermediate appellate courts of the federal court system. A court of appeals decides appeals from the district courts within its circuit and in some instances from other designated federal courts and administrative agencies.

${ }^{26}$ The 1997 Polish constitution has approximately 20,300 words, compared to less than 5,000 words in the U.S. Constitution. The Polish constitution's discussion of just the Constitutional Tribunal is substantially longer than the U.S. Constitution's discussion of the Supreme Court (see fn 5):

Article 194. 1. The Constitutional Tribunal shall be composed of 15 judges chosen individually by the Sejm for a term of office of 9 years from amongst persons distinguished by their knowledge of the law. No person may be chosen for more than one term of office...

Article 195. 1. Judges of the Constitutional Tribunal, in the exercise of their office, shall be independent and subject only to the Constitution...

3. Judges of the Constitutional Tribunal, during their term of office, shall not belong to a political party, a trade union or perform public activities incompatible with the principles of the independence of the courts and judges...

Article 197. The organization of the Constitutional Tribunal, as well as the mode of proceedings before it, shall be specified by statute. [bolding added] 
Comparing The Polish and American Court Systems. One can roughly understand court systems in the United States as follows. For the most part each state has its own court system, with ordinary trial courts and administrative courts, appeals courts above them and a supreme court for final appeals. Each state's courts deal with disputes between the state's citizens and between the state government and its own citizens.

The U.S. Constitution specifies the jurisdiction and duties of U.S. federal courts:

Article III...Section 2. 1: The judicial Power shall extend to all Cases, in Law and Equity, arising under this Constitution, the Laws of the United States, and Treaties made, or which shall be made, under their Authority;- - to all Cases affecting Ambassadors, other public Ministers and Consuls; - to all Cases of admiralty and maritime Jurisdiction;- - to Controversies to which the United States shall be a Party; - to Controversies between two or more States; - between a State and Citizens of another State; ${ }^{27}$-between Citizens of different States, - between Citizens of the same State claiming Lands under Grants of different States, and between a State, or the Citizens thereof, and foreign States, Citizens or Subjects.

Similarly, in a rough way, Poland has common courts that "implement the administration of justice concerning all matters save for those statutorily reserved to other courts." Above the common courts is the Supreme Court that "exercise[s] supervision over common...courts regarding judgments...[and] perform [s] other activities specified in the Constitution and statutes." In addition the Constitutional Tribunal decides on all sorts of constitutional matters, comparable in this respect to the U.S. Supreme Court. An additional institution is the National Council of the Judiciary, without particular powers specified in the constitution (The Constitution of the Republic of Poland, chapter VIII, art. 175, 178, 179, 183, 187-190, 194, 195 \& 197). The PiS has passed laws giving the National Council, dominated by PiS appointees, great control over the Supreme Court and ordinary courts. For excellent discussions of the facts of the Polish court-packing case, see Matczak (2018a, 2018b). See also Davies (2018a, 2018b), GRECO (2018), Letowska (2018), Santora (2018), Mazur and Żurek (2017) and Szczerbiak (2017, 2018).

Two Types of Court Packing. "Court packing" has negative connotations. But court packing has at least two denotations, one morally legitimate, the other illegitimate, potentially quite dangerous. When President Trump nominated Judge Brett Kavanaugh on July 9, 2018, to fill a vacant Supreme Court seat, the opposition Democrats accused Trump of trying to pack the Court. The Democrats deeply meant negative connotations but the substance was ordinary politics, wholly constitutional, no sleight of hand, no moral problem. The substance was that four of the nine Supreme Court Justices leaned

\footnotetext{
${ }^{27}$ Amendment XI affects Article 3 Section 2 Clause 1.
} 
substantially left, four substantially right, and the swing vote, Justice Anthony Kennedy, leaning sometimes to one side, sometimes the other, was retiring at age 81 . Trump, a Republican, had promised to nominate a conservative judge to replace the more middle-of-the-road Kennedy and in Kavanaugh he did. The Court would thereafter have a five-to-four conservative to liberal split—until the next appointment. Under the Constitution, Trump had every right to nominate Kavanaugh; but the Constitution required the Senate to approve the nomination by majority vote for Kavanaugh to be seated. Sadly for Democrats the Republicans held a 51-49 majority. Of course the Democrats would-had to, politically_complain loud and long about court packing, forget accuracy. Kavanaugh's nomination was just one of many bad and sad political consequences Democrats faced when Trump won the 2016 presidential election. In usage more respectful of the English language, Trump was allowed to "pack" the Court because he did it the old-fashioned way: He won elections.

The serious, negative version of court packing, potentially very dangerous, is for the party in power to change laws about courts to let it add to the total number of judges people with the party's ideology or to remove some judges for the purpose of changing the court's ideological balance (see Roosevelt's court-packing attempt above). Such behavior may set off tit-for-tat swings in court packing as parties rotate in power. ${ }^{28}$ Worse, such nakedly political fiddling likely undermines popular respect for the executive, legislature and the packed courts.

PiS is going to appoint judges while it is in power. A balanced view of PiS appointments is that vacancies arising by retirement or resignation, but not from PiS changes in laws, are legitimate. The former are the spoils of political warfare, as in the United States. In contrast, changing laws to pack courts is illegitimate and dangerous to the polity.

Comparing court packing in the United States and Poland is useful, but there is a major difference between the two countries. No authority outside the United States may judge federal court packing. ${ }^{29}$ Poland, however, is a member of the European Union, and EU-level institutions may review, condemn or punish court packing in Poland. Thus, it is worthwhile to consider an attempt by a U.S. state to pack its courts and how the U.S. federal government and judiciary might respond.

The PiS government succeeded in packing the Constitutional Tribunal without a great deal of trouble. It has packed the National Council with members

${ }^{28}$ Opponents of Democratic court-packing plans argue that if the plans succeeded, Republicans would undo them when returned to power, might retaliate with their own courtpacking-exploding retaliation?

${ }^{29}$ United States citizens esteem views of few international organizations, and none have a U.S. constitutional role. 
who would do its will, and has given the Council powers to bend lower courts to PiS will. The PiS is close to success in packing the Supreme Court. It is on the grounds of packing the Supreme Court that EU institutions have chosen to challenge PiS ambitions.

\section{What to do if a member state goes wrong constitutionally}

Supremacy over States. The U.S. federal government may sometimes intervene in the affairs of a state. The U.S. Constitution contains a number of justifications for such intervention. The major one historically is the Supremacy Clause (U.S. Constitution):

Article VI....This Constitution and the Laws of the United States which shall be made in Pursuance thereof; and all Treaties made, or which shall be made, under the Authority of the United States, shall be the supreme Law of the Land; and the Judges in every State shall be bound thereby, any Thing in the Constitution or Laws of any State to the Contrary notwithstanding...

The ECJ's supremacy is not so clear (Lisbon Treaty, 2017; Kumm \& Ferrera Comella, 2005):

17. Declaration concerning primacy. The Conference recalls that, in accordance with well settled case law of the Court of Justice of the European Union, the Treaties and the law adopted by the Union on the basis of the Treaties have primacy over the law of Member States, under the conditions laid down by the said case law. [italics added]

Among other member states Poland has entered objections to this $\mathrm{EU}^{30}$ assertion of supremacy.

Grounds for Appeal in the United States. Since the Constitution went into effect in 1789 an enormous body of federal legislation has accumulated and many federal decisions-from lower federal courts to the Supreme Court-have built up. Almost as soon as the Constitution came into effect, the Supreme Court reviewed state laws and state-court decisions for their consistency with federal law and the Constitution ("judicial review"), rejecting those not consistent. The parts of the Constitution most often cited in arguments over the constitutionality of state laws are in the first ten amendments to the Constitution, "the Bill of

${ }^{30}$ Sweeney (2018) argues that many EU difficulties arise from the gradual approach to the European Project, one treaty, then another, never knowing what the European Union would be in ten years. Further, citizens seldom get a direct vote on a treaty. Because many citizens are skeptical of their governments, parliamentary approval does not give the same legitimacy as a referendum. To be sure, referenda are crude, imperfect devices. Rather, the U.S. Constitution was approved in each state, after debate, by an assembly called for that one purpose, with delegates selected by the people. This is the only approximation to a federal referendum in U.S. history. The people knew what they would be getting, including the Supremacy Clause, for several generations. An ECJ opponent may say, "We never voted for that." 
Rights." These explicitly aim at protecting people against the U.S. government, but not state governments. As seen below, almost all now apply to the states. For comparison to EU law below, take three amendments dealing with justice:

Amendment IV: The right of the people to be secure in their persons, houses, papers, and effects against unreasonable searches and seizures shall not be violated, and no warrants shall issue but upon probable cause, supported by oath or affirmation, and particularly describing the place to be searched and the persons or things to be seized.

Amendment V: No person shall be held to answer for a capital or otherwise infamous crime unless on a presentment or indictment of a grand jury[;] ... nor shall any person be subject for the same offense to be twice put in jeopardy of life or limb; nor shall be compelled in any criminal case to be a witness against himself, nor be deprived of life, liberty, or property without due process of law...

Amendment VI: In all criminal prosecutions, the accused shall enjoy the right to a speedy and public trial by an impartial jury of the state and district wherein the crime shall have been committed... and to be informed of the nature and cause of the accusation; to be confronted with the witnesses against him; to have compulsory process for obtaining witnesses in his favor; and to have the assistance of counsel for his defense.

Beyond the Bill of Rights, an important addition is the post-Civil War Fourteenth Amendment:

Amendment XIV - Section 1. All persons born or naturalized in the United States and subject to the jurisdiction thereof, are citizens of the United States and of the State wherein they reside. No State shall make or enforce any law which shall abridge the privileges or immunities of citizens of the United States; nor shall any State deprive any person of life, liberty, or property, without due process of law; nor deny to any person within its jurisdiction the equal protection of the laws...

Under the amendment, no state may "abridge the privileges or immunities of citizens ${ }^{31}[$,]" "deprive any person of life, liberty, or property, without due process of law[,]"32 or "deny to any person within its jurisdiction the equal protection of the laws." Moreover, starting in the early twentieth century, the Supreme Court has decided-amendment by amendment, clause by clausethat most, though not all, of the Bill of Rights' restrictions on the federal government also restrict state governments.

For citizens who believe that their state government is imposing requirements or restraints on them that are unconstitutional under U.S. laws or the U.S. Constitution, likely their first method to obtain redress is to turn to U.S. courts. Citizens who believe that their state government is infringing their right to vote, for example, may turn to U.S. courts to claim that state laws or proce-

\footnotetext{
${ }^{31}$ This is in addition to the Privileges and Immunities Clause in the Constitution itself.

${ }^{32}$ This is in addition to the Due Process Clause in the Fifth Amendment.
} 
dures are illegal under U.S. civil rights laws or are unconstitutional under the equal protection clause of the Fourteenth Amendment. The citizens may ask a federal court ${ }^{33}$ for an injunction that forbids the state from acting as it currently does or proposes. Assuming they ask a district federal court, there is a single judge, who may take a wide range of actions: the judge may deny the petition completely-or may issue a permanent injunction forbidding the state action. Whatever the district court outcome, one side or both may turn to the federal appeals' court that oversees the particular district judge. The appeals' court faces essentially the same choices as the district court. Whatever the appeals' court decides, if each side is determined and has adequate resources, one or both appeals to the Supreme Court. ${ }^{34}$ The Supreme Court eithers declines to take the case, and the default is whatever the latest court ruled-or the Court faces a range similar to above. If the Court rules against the state it relies on the executive branch to enforce its ruling.

Member-State Citizens Appeal against their Government to the EU Level. The European Union differs in two ways. First, the citizen's appeal to the EU commission (the executive branch) or the EU Parliament (the legislative branch), rather than the European Court of Justice. Second, the grounds for appealing to the EU level are much less concrete and specific than under the U.S. Constitution. ${ }^{35}$

Article 2 of the Lisbon Treaty is the basis of EU action against Poland. It is much less concrete and explicit and protects fewer personal rights than U.S. Constitutional law:

Article 2. The Union is founded on the values of respect for human dignity, freedom, democracy, equality, the rule of law and respect for human rights, including the rights of persons belonging to minorities. These values are common to the Member States in a society in which pluralism, non-discrimination, tolerance, justice, solidarity and equality between women and men prevail. ${ }^{36}$

${ }^{33}$ In most cases the complaint goes to a federal district court, the lowest level federal court. In relatively rare cases the complaint may go directly to the Supreme Court, but unless such case falls under those where the Supreme Court is specified (under the Constitution or Congressional acts) as the initial court, the Court is unlikely to hear it.

${ }^{34}$ If the appeals' court gives something to one side but something to the other, both may appeal.

${ }^{35}$ Compare the First Amendment above to Article 2 below.

${ }^{36}$ This formulation raises a number of issues in common with understanding the U.S. Constitution. Does the phrase "the values of respect for human dignity, freedom, democracy, equality, the rule of law and respect for human rights, the values of respect for human dignity, freedom, democracy, equality, the rule of law and respect for human rights, including the rights of persons belonging to minorities[,]" enumerate all and only the values to be protected? Are they simply illustrative? Does the differences in nouns between the first sentence and the next, "These values are common to the Member States in a society in which pluralism, non-discrimination, tolerance, justice, solidarity and equality between women and men prevail[,]" mean the that the nouns in the second sentence add to the "values" in the first? Illustrate them? Expand them? Limit them? 
In American law many simple English phrases have become "terms of art." In the United States, "due process of law," is a term of art; its meaning has been debated and has changed over time, but in most cases its technical meaning is clear. In terms of international law and EU law often it is not clear what is meant by "respect for human dignity, freedom, democracy, equality, the rule of law and respect for human rights, including the rights of persons belonging to minorities[,]" if these terms are taken as terms of art. It may be unclear, then, what is meant by charges that a country has offended against values in Article 2.

Based on Article 2 above, EU central institutions are threatening action against the Polish government under Article 7:

Article 7. 1. On a reasoned proposal by one third of the Member States, by the European Parliament or by the European Commission, the Council, acting by a majority of four fifths of its members after obtaining the consent of the European Parliament, may determine that there is a clear risk of a serious breach by a Member State of the values referred to in Article 2. Before making such a determination, the Council shall hear the Member State in question and may address recommendations to it, acting in accordance with the same procedure...

Appealing to the Supreme Court vs. the EU Executive/Legislative Branches. If citizens of a U.S. state raise constitutional issues to the federal level against a state government, they go to federal courts. Polish opponents of the actions of the PiS government rely on the European Commission, in the first instance, and the European Council and the European Parliament. ${ }^{37}$

EU institutions threaten, if negotiations with the PiS government fail, to raise the dispute to the European Court of Justice. As things stand in late August, 2018 (EU Commission-Press release, August 14, 2018):

On August 14, 2018, "the European Commission decided to send a Reasoned Opinion to Poland regarding the Polish law on the Supreme Court... The European Commission maintains its position that the Polish law on the Supreme Court is incompatible with EU law as it undermines the principle of judicial independence, including the irremovability of judges, and thereby Poland fails to fulfil its obligations under Article 19(1) of the Treaty on European Union read in connection with Article 47 of the Charter of Fundamental Rights of the European Union. [bolding in original]

The Articles to which the press release refers are:

Treaty on European Union: Article 19.

1. The Court of Justice of the European Union shall include the Court of Justice, the General Court and specialized courts. It shall ensure that in the interpretation and application of the Treaties the law is observed...

${ }^{37}$ To be clear: In both the United States and the European Union, the executive branches need not wait for citizen complaints before moving forward. 
European Union Charter of Fundamental Rights: Article 47. Right to an effective remedy and to a fair trial

Everyone whose rights and freedoms guaranteed by the law of the Union are violated has the right to an effective remedy before a tribunal in compliance with the conditions laid down in this Article.

Everyone is entitled to a fair and public hearing within a reasonable time by an independent and impartial tribunal previously established by law. Everyone shall have the possibility of being advised, defended and represented... [bolding added]

An Institution's “Reservoir of Goodwill." Sending such cases to courts is preferable in the United States to sending them to the executive branch or Congress. As noted above, federal courts have great experience with constitutional cases. To be sure, on major issues U.S. federal courts have sometimes fallen short. ${ }^{38}$ Further, since at least the 1950s, the Court has made major decisions that have angered many Americans. Still, some Court decisions have been applauded, many have not been controversial and relatively few have been closely split along ideological lines. The Court has enough remaining prestige, and citizens a strong enough tradition of acquiescing in Court constitutional decisions, to make Court decisions acceptable to a substantial proportion of citizens; the Court has a "reservoir of goodwill." Once the Court decides many citizens who do not like the decision peaceably accept that their remaining options are to convince enough people to use political power to enact legislation that passes constitutional scrutiny, to amend the Constitution, or to change the Court's ideological composition to reverse the decision.

Polls have long shown that the reservoir of goodwill is close to dry for the U.S. federal executive and legislative branches. Any major, controversial decision they make is likely to be split on party lines and to outrage half of the country.

A "Reasoned Opinion" from the European Commission is unlikely seriously to sway Poles who support PiS or have some sympathy with their views. Eurobarometer surveys have shown for a number of years that the majority of residents of many EU member states have negative views of EU institutions; perhaps it had to be, but EU institutions have depleted their reservoir of good-

${ }^{38}$ One example is Dred Scott v. Sandford (1857), a disgraceful Court decision supporting slavery that gravely tarnished the Court's reputation for a generation (Fehrenbacher 1978). Perhaps the most important modern example is Roe v. Wade (1973): It legalized abortion in all states and gave the Supreme Court the final word on state regulations. Before, individual states seriatim worked out legalization and restrictions; different states had different regulations. Roe made abortion a bitter, ongoing, national issue. (Heagney 2013.) More recent is National Federation of Independent Business v. Sebelius (2012) on Obamacare (Patient Protection and Affordable Care $A c t)$. The Court upheld key Obamacare provisions. The decision was a mess; few defend or respect it. It settled nothing. 
will. Thus, a Reasoned Opinion is unlikely to stir substantial popular opposition in EU member states against the PiS.

The European Court of Justice (established 1952) has a much shorter record and body of decisions. Further, its power increased substantially under the Maastricht Treaty (1992), making its meaningful record smaller. It is not clear that EU residents have more goodwill for the ECJ than other EU institutions. The ECJ has a reputation of being a highly political institution-no suggestion here of "Fiat justicia, ruat caelum." ${ }^{39}$ Moreover, EU tradition is to finesse crises: Any ECJ ruling is likely to have relatively little teeth in the near term, though its rhetoric may be severe for Poland's obstreperous, disliked government.

Will the Supreme Court Rule? In several U.S. states, legislators have proposed packing state courts. No state has enacted such laws (Gavel to Gavel, 2016, 2013). If one were enacted, certainly people and organizations would petition federal courts to overturn the state law as violating the U.S. Constitution. No body of court decisions deals with state court-packing to guide federal courts; an observer has no clear guide in predicting federal court decisions. Likely some entity would petition a federal district judge in the state to grant an injunction preventing the court-packing law from taking effect. Discussion above shows the range of possible decisions, appeals, etc., from the district court up to the Supreme Court.

Court packing charges, however, raise another possibility. The district, appeals', or ultimately the Supreme Court might dodge the issue by declaring it a "Political Question." The Supreme Court would likely hear the case eventually, but might decline to rule because it was a political issue, not a judiciable issue. Political questions are to be decided by the federal or state legislatures or executives, not by the court, a view the Court first enunciated in Marbury v. Madison (1803). In one view the Political Question Doctrine is a scholarly issue in which deep and subtle analysis divines meanings and parameters (for example, Harrison 2017). In another, it is a dodge for the Supreme Court (and sometimes lower courts) to protect itself from political exposure from deciding cases where citizens are widely split and any decision likely to undermine the Court's standing. ${ }^{40}$

${ }^{39}$ Latin for, "Let justice be done, though the heavens fall." The phrase is nineteenth century, not classical.

${ }^{40}$ The Supreme Court has taken cases and made decisions that it might well have avoided, perhaps by declaring them political questions. A key example is Roe v. Wade (1973) on abortion.

The Court apparently will avoid any case dealing with the Constitution's "Guarantee Clause." Baker v. Carr (1962): Article IV, section 4, of the Constitution "guarantee[s] to every State in this Union a Republican Form of Government." Neither will the Court involve itself in impeachment and trials of federal executive officers, nor with whether a treaty continues or has been terminated. The Court strongly avoids most issues of whether a war is constitutional (for 
Supreme Court decisions almost always depend on the facts of the case (Harrison 2017). ${ }^{41}$ Suppose California, with the largest state population, after decades of complete Democratic dominance, looks like it will have a Republican governor who will get to appoint some state supreme court justices. In response, before the Republicans take over, the Democratic legislature increases the number of justices, whom the Democratic executive then appoints. Suppose the increase is from nine to eleven and the law is not a noisy exercise in court packing. Alternatively, suppose the increase is from nine to eighteen and the court packing is obvious, virtually a reality show (as U.S. court packers seem always to be). But change the facts from large, Democratic California to small, Republican Wyoming, a small state and largely Republican. Would the alternative facts matter to the justices?

Enforcing a High-Court Decision. How might a court-packing decision of the Supreme Court or ECJ be enforced? The Supreme Court might rule (should it not use the Political Question dodge) that a particular state's court packing is unconstitutional; the situation must revert to the status before the law. The ECJ is quite likely to rule in favor of the European Commission and against the Polish government. Perhaps the ECJ will order the Polish government to revert to the status quo ante. What might a U.S. state or Poland do in response? How might central authorities enforce the high court ruling?

U.S. Use of Force to Implement Court Rulings. The 1954 Supreme Court decision in Brown v. Topeka outlawed segregation in public schools. In 1957 Arkansas Governor Orville Faubus, a Democrat, refused to obey court orders to allow black students to register for public school in the Arkansas capital, Little Rock. President Dwight D. Eisenhower, a Republican, nationalized the Arkansas National Guard and sent in 1000 troops from the Army's 101st Airborne Division to enforce school integration (Lewis 1957). ${ }^{42}$ Eisenhower's executive action was his, not the Supreme Court's. Eisenhower showed great political courage; use of force is always a possibility, but a politically-conditioned possibility.

California or Wyoming would almost certainly never use force to defy a Supreme Court court-packing decision; federal laws and courts are su-

example, Schlesinger v. Holtzman). The Court sometimes gets involved in gerrymandering cases, but usually is wary.

${ }^{41}$ But not always. The Dred Scott case seems simply to have been a highly ideological disaster with weak analysis and willful avoidance of facts (Fehrenbacher, 1978).

${ }^{42}$ In 1963, George Wallace (D, Alabama) stood in a university building's doorway to prevent two black students from registering. "When Wallace refused to budge, President John F. Kennedy (D) called for 100 troops from the Alabama National Guard to assist federal officials. Wallace chose to step down rather than incite violence" (Bell, 2013). A television moment. If Kennedy backed down, Wallace won. If Kennedy sent troops or perhaps a single U.S. marshal, Wallace backed down but reveled in making his point. Still, it was a difficult decision for Kennedy, who was not a strong civil-rights advocate and many Democratic politicians were segregationists. 
preme. ${ }^{43}$ In either state: Raving and complaining, protests, petitions, politicians burned in effigy, thundering demagogues, threats and allegations...but very low probability of violent resistance. But what of non-violent resistance?

It hard to see how an ECJ decision would be self-enforcing. If the ECJ issues a decision requiring the PiS government to mitigate or reverse court packing, PiS is unlikely to go quietly. Certainly EU countries would never use force to make PiS comply. Rather, after dilatory actions, as prolonged as possible, PiS would likely make nugatory changes. PiS supporters would strongly reject the decision and vilify ECJ legitimacy, claiming EU institutions are so biased against Poland as to lack legitimacy. Opponents would return to the ECJ. After typically prolonged proceedings the ECJ would make further decisions, followed by appeals and other delays-and then perhaps further nugatory changes by PiS. And so on. Each side is likely to rely on the Micawberish hope that "something will turn up" (Dickens, 2004). From the EU viewpoint perhaps PiS suffers a disastrous electoral defeat, the victors revert to the status quo ante, the problem disappears. PiS may hope that various other crises will preoccupy the EU institutions: a sequence of Euro crises and/or banking crises, another Great Recession, a Brexit so disastrous that Polish issues are the least of their worries-see below.

Consider what the U.S. government might do if California or Wyoming should defy a Supreme Court ruling on court packing. To start with the government or Court might decide that all of the state's supreme court's post-packing decisions are invalid-perhaps any state court decisions post-packing is invalid. What about enforceability of contracts in the defiant state, especially banking and financial contracts? Recall that the U.S. government can impose great nonviolent punishments on say Iran and those dealing with Iran and it could impose much greater ones on a state. One thing that might slow federal punishment is how Americans would see the punishment. The great majority of Democratic politicians and partisans might noisily oppose a Republican president's moves against California (and the same mutatis mutandis for a Democratic president's move against Wyoming).

Moderate ECJ legal and financial actions against PiS might not spark much EU outrage; PiS actions have little support among EU. member-state governments beyond Hungary and perhaps the Czech Republic and Slovakia. EU citizens on average show little connection to the PiS; busting PiS over court packing is unlikely to stir popular trouble as immigration might. Still, EU-level institutions must step carefully and must focus on Polish issues. First, in the

${ }^{43}$ Each state has its own National Guard, similar to a militia. In normal times, the governor is in charge. The president, however, can nationalize any state National Guard, as Eisenhower did in Little Rock. No state has its own army, navy or air force. Further, any local or state police who resist U.S. forces would be subject to severe penalties.

The situation is far different for EU states. There is no EU military. EU central institutions have no powers to nationalize member-state armed forces. 
majority of EU member states less than half of poll respondents have positive feelings about their own governments or EU-level institutions. Second, EU institutions face many pressing issues beyond PiS power plays: Brexit and its fallout; banking union; ongoing economic-financial problems in Greece, possible problems with Italy and Spain; tariff wars; defense spending and NATO relations; the EU budget; holding together EU dealings with Russia; setting immigration policies; assimilation of large numbers of recent immigrants, mostly young, single, poorly educated, with little knowledge or respect for western cultures; and many more. EU leaders deeply understand prioritization and are deeply skilled at infighting to get the prioritization each wants. Where will the threats of PiS action come on the list?

Third, coordinated actions will be more effective against PiS. The European Union must develop an effective, joint, sellable strategy against PiS's takeover. Only then can it organize other democracies for coordinated pressure on PiS, political, economic, financial. Which countries might have weight against the PiS takeover? Consider non-EU members of the Group of Ten, European Free Trade Area, and Group of Twenty. ${ }^{44}$ Non-EU countries with democratic stature are: Canada, Japan, Switzerland, the United Kingdom (after Brexit), the United States; Iceland, Liechtenstein, Norway; Australia, India, and Korea. ${ }^{45}$ The European Union must get beyond its quarrels with the United Kingdom over Brexit and quarrels with the United States over trade, defense and more in order to deal jointly and effectively with Poland's danger.

\section{Conclusions}

In 1937, U.S. President Franklin D. Roosevelt, a Democrat, tried to pack the Supreme Court; in 2016-2018, the PiS government tried to pack the Polish Constitutional Tribunal and Supreme Court and to dominate ordinary Polish courts and is close to succeeding. This, despite the U.S. Constitution declaring the court system a separate, independent branch with its own specified powers and the Polish constitution explicitly guaranteeing the court system's independence. How did America dodge the bullet that is lodged in Poland's judicial heart? Certainly not because Americans are superior to Poles, or the U.S. Constitution contains stronger guarantees against court packing than the

${ }^{44}$ G-10: Belgium, Canada, France, Germany, Italy, Japan, the Netherlands, Sweden, Switzerland, the United Kingdom and the United States. EFTA: Iceland, Liechtenstein, Norway and Switzerland. G-20: Argentina, Australia, Brazil, Canada, China, France, Germany, India, Indonesia, Italy, Japan, Republic of Korea, Mexico, Russia, Saudi Arabia, South Africa, Turkey, the United Kingdom, the United States and the European Union.

${ }^{45}$ Some might not include India or Korea. EFTA members might be viewed as part of the European Union. 
Polish constitution-it does not. Rather, Roosevelt's Democratic Party was a coalition that he could not dominate.

America had a good deal more luck in 1937 than Poland has had. In polls only a few percent more Americans opposed court packing than supported it; Republicans disliked it strongly, but a good majority of Democrats liked it. The key is that Roosevelt's Democrats strongly controlled both houses of Congress, but Roosevelt did not control his party. A number of important Democrat senators strongly opposed this court-packing attempt as unconstitutional. Roosevelt's plan never even reached the floor of the Senate for debate.

The PiS, in contrast, is an extreme example of some European parties where leaders may be very powerful; a single man and his close, subordinate aides, dominate PiS. Democrats in Congress in 1937 could oppose their party leader, not so PiS members now. The PiS seems largely to have succeeded in packing the Constitutional Tribunal, the Supreme Court and the National Council of the Judiciary, institutions that dominate ordinary courts.

U.S. constitutional history may offer insight for Poland's struggles in two ways. First, one may compare the United States to Poland, one country to another. One may compare an individual American state to Poland, because the United States is an organization of states and so is the European Union, an organization to which Poland belongs.

If legislation packing the Supreme Court were enacted into law now in the United States, the Court might rule on it, presumably overturning it. Suppose the government refused to back down? What would happen? One can imagine a myriad of possible paths, many leading to one crisis after another, perhaps to chaos. Alternatively, to avoid a constitutional crisis, the Court might declare this a "Political Question," for the executive or legislative branches to decide. This alternative relies on scheduled elections to allow rotation in power to repair court-packing damage. Suppose had Roosevelt succeeded 1937; in fact, Republicans retook the presidency only in 1953-it demands substantial patience to wait 16 years. The Republicans might have been harsher than simply reversing Democrats' illegitimate actions. If the Democrats were going to undermine the Constitution through court packing whenever in power, Republicans might do their own court packing.

The above U.S. scenarios suggest two points for Poland. First, why did the Constitutional Tribunal "go quietly," and why did the Polish Supreme Court not resist more strongly, perhaps to the extent of forcing imprisonment and trialsconstitutional crises? ${ }^{46}$ Where would such internal resistance end? And what would it do to Poland? Second, if future elections are honest and fair and political control rotates between the PiS and its liberal opponents, what will the liberal opponents do in response to PiS court packing? When PiS loses office

${ }^{46}$ This is not to say that Polish Supreme Court members who resisted were not brave. Rather, the question is whether the brave think it wise to push to possible civil chaos, and if so, when. 
will its liberal opponents decide to forgo revenge and, more importantly, find a way to stop any court packing?

Poland faces worse than court packing. There is no evidence Roosevelt and his closest aides planned to prevent Republicans from ever returning to power, though they thought their taxing-spending policies were so politically powerful that they might retain power indefinitely. ${ }^{47}$ They abhorred the Republican opposition but did not think it deeply tainted and illegitimate. In contrast, PiS views the opposition as illegitimate, riddled with Communists, fatally tainted by ties to the communist dictatorship and the oligarchs that followed, unworthy of rotation in power. PiS has more powers to maintain control of the government than did Roosevelt, for example, centralized control of schools. Roosevelt famously made his radio "Fireside Chats" to the entire country, but radio also broadcast much opposition. PiS, however, controls television in Poland, radio's more powerful successor. In America in 2018, political programs on radio are mostly Republican, but by objective measures most television stations incline strongly to Democrats. Internet blogs, news aggregators and podcasts are wildly independent in political leanings and willing to oppose the government. In some Polish regions independent internet sources are not as important relative to TV as in the United States. Liberal opposition in Poland may face a difficult, prolonged fight to recreate an independent judiciary.

Poland's best hope to preserve its freedom is action by EU-level institutions. EU institutions hold the legal, financial, and diplomatic upper hand over Poland. The EU-PiS conflict, however, is political and the internal Polish battle is to sway those who support PiS. But PiS supporters give little credit to EU institutions and see EU member states as largely dominated by EU institutions. The European Union thus needs as strong international support as possible from major democratic countries, to offset PiS support from a few anti-liberal EU members and opportunistic, non-democratic non-EU. countries The key liberal countries in this contest are the United Kingdom and the United States. The harsh Brexit and EU-U.S. conflicts hinder efforts to form a strong, united front against threats to Polish liberal democracy. The European Union needs to make the threats to Poland a top priority, not one goal among many.

\section{References}

Accession criteria (Copenhagen criteria). EUR-LEX. Retrieved from https://eur-lex. europa.eu/summary/glossary/accession_criteria_copenhague.html

Bell, D. (2013, June 11). George Wallace stood in a doorway at the University of Alabama 50 years ago today. USA Today. Retrieved from https://www.usnews.com/news/

\footnotetext{
${ }^{47}$ Columnist Arthur Krock reported in 1938 that Harry Hopkins, one of Roosevelt's top and longest lasting advisers, said in the presence of Roosevelt and others, 'We will spend and spend, and tax and tax, and elect and elect.'
} 
blogs/press-past/2013/06/11/george-wallace-stood-in-a-doorway-at-the-university-of-alabama-50-years-ago-today

Blackman, J. (2017, November 27). Republicans should not pack the courts. National Review. Retrieved from https://www.nationalreview.com/2017/11/republicanscourt-nominations-congress-shouldnt-pack-courts/

Calabresi, G., (2017, November 24). It wouldn't be 'court-packing' for Republicans to expand the federal courts. National Review. Retrieved from https://www.nationalreview.com/corner/it-wouldnt-be-court-packing-republicans-expand-federalcourts/

Calabresi, G. \& Hirji, S. (2017, November 27). Judicial appointments after judge Robert H. Bork. Balkinization. Retrieved from https://balkin.blogspot.com/2017/11/judicial-appointments-after-judge.html

Calabresi, G. \& Hirji, S. (2018, July 20). Working Paper, taken down from SSRN and not re-posted as of July 20, 2018.

Carter, Z. (2018, June 27). Hey, Democrats: Pack the Court. HuffPost. Retrieved from https://www.huffingtonpost.com/entry/hey-democrats-pack-the-court_ us_5b33f7a8e4b0b5e692f3f3d4

Constitution of the Republic of Poland (1997, April 2). Retrieved from http://www. sejm.gov.pl/prawo/konst/angielski/kon 1.htm

Davies, C. (2018a, May). Hostile Takeover: How law and justice captured Poland's courts. Nations in Transition Analytical Brief. Freedom House. Retrieved from: https:// freedomhouse.org/report/special-reports/hostile-takeover-how-law-and-justicecaptured-poland-s-courts

Davies, C., (2018b, July 2). Poland's supreme court constitutional crisis approaches a standoff. Guardian. Retrieved from https://www.theguardian.com/world/2018/ jul/02/polands-supreme-court-constitutional-crisis-comes-to-a-head

Dickens, C. (2004). David Copperfield. London: Penguin Classics.

E.U. Commission (2018, August 14). Press Release. Brussels.

Fehrenbacher, D. (1978). The Dred Scott case. Its significance in American law and politics. New York, NY: Oxford University Press.

Gavel to Gavel. Over a dozen efforts to alter number of state supreme court justices, almost all related to "packing" the courts, in last several years. Retrieved from http:// gaveltogavel.us/2013/02/05/over-a-dozen-efforts-to-alter-number-of-state-supremecourt-justices-almost-all-related-to-packing-the-courts-in-last-several-years/

Gavel to Gavel. Plans to add 2 justices to the Arizona and Georgia supreme courts pass committee hurdles; critics call them court packing plans. Retrieved from http:// gaveltogavel.us/2016/03/17/plans-add-2-justices-arizona-georgia-supreme-courtspass-committee-hurdles-final-floor-votes-happen-soon/

Goodman, R. (2018, July 04). Hey, Democrats, fighting fair is for suckers. Court-packing! Puerto Rican statehood! Votes for felons! Why-and how-the next Democratic majority should play dirty. Politico. Retrieved from https://www.politico.com/ magazine/story/2018/07/04/democrats-majority-rules-norms-trump-2020-218947

GRECO. (2018,19-23 March). Ad hoc Report on POLAND (Rule 34). Adopted by GRECO at its 79th Plenary Meeting.

Harrison, J. (2017). The political question doctrines. American University Law Review, $67,457-528$. 
Heagney, M. (2013, May 15). Justice Ruth Bader Ginsburg offers critique of Roe v. Wade during Law School visit. University of Chicago Law School. Retrieved from https://www.law.uchicago.edu/news/justice-ruth-bader-ginsburg-offers-critiqueroe-v-wade-during-law-school-visit

Krock, A., (1938, November 9). Win back 10 states; Republicans take Ohio, Wisconsin, Kansas and Massachusetts. New York Times, 1.

Kumm, M. \& Ferreres Comella, V. (2005). The primacy clause of the constitutional treaty and the future of constitutional conflict in the European Union. International Journal of Constitutional Law, 3, 473-492. doi: 10.1093/icon/moi029

Letowska, E. (2018, February 20). Position of the Helsinki Committee in Poland. An open letter. Public Seminar. Retrieved from http://www.publicseminar.org/2018/02/ position-of-the-helsinki-committee-in-poland/

Leuchtenburg, W.E. (1995). The Supreme Court reborn: The constitutional revolution in the age of Roosevelt. New York, NY: Oxford University Press.

Lewis, A. (1957, September 24). President sends troops to Little Rock, federalizes Arkansas National Guard, tells nation he acted to avoid an anarchy. New York Times. Retrieved fromhttps://archive.nytimes.com/www.nytimes.com/learning/general/ onthisday/big/0925.html\#article

Lisbon Treaty. (2017). Consolidated protocols, annexes and declarations attached to the treaties of the European Union/Declarations. Retrieved from https://en.wikisource. org/wiki/Consolidated_protocols,_annexes_and_declarations_attached_to_the_ treaties_of_the_European_Union/Declarations\#17._Declaration_concerning_primacy

Lithwick, D. (2017, November 22). Judges over principles. The never-Trump legal movement has morphed into a push to pack the courts with Trump-selected judges. Slate. Retrieved from http://www.slate.com/articles/news_and_politics/jurisprudence/2017/11/the_never_trump_legal_movement_has_morphed_into_a_plan_ to_pack_the_courts.html

Matczak, M. (2018a, March 8). Poland: From paradigm to pariah? Polish constitutional crisis-facts and interpretations. Oxford: Lecture.

Matczak, M. (2018b, July 6). Poland's Constitutional Crisis: Facts and interpretations. Oxford: The Foundation for Law, Justice and Society.

Matthews, D. (2018, July 10). Court-packing, Democrats' nuclear option for the Supreme Court, explained. Vox. Retrieved from https://www.vox.com/2018/7/2/17513520/ court-packing-explained-fdr-roosevelt-new-deal-democrats-supreme-court

Mazur, D. \& Zurek, W. (2017). The judiciary in Poland at the threshold of 2017: Challenges and threats. Ruch Prawniczy, Ekonomiczny i Socjologiczny, 79(1), 25-38.

McKenna, M.C. (2002). Franklin Roosevelt and the Great Constitutional War: The courtpacking crisis of 1937. New York, NY: Fordham University Press.

Millhiser, I. (2015 February 23). In defense of court-packing. Slate. Retrieved from http://www.slate.com/articles/news_and_politics/jurisprudence/2015/02/fdr_ court_packing_plan_obama_and_roosevelt_s_supreme_court_standoffs.html

Primus, R. (2017, November 24). Rulebooks, playgrounds, and endgames: A constitutional analysis of the Calabresi-Hirji judgeship proposal, Harvard Law School Blog. Retrieved from https://bTYlog.harvardlawreview.org/rulebooks-playgrounds-andendgames-a-constitutional-analysis-of-the-calabresi-hirji-judgeship-proposal/ 
Right to an effective remedy and to a fair trial. EU Charter of Fundamental Rights. http:// fra.europa.eu/en/charterpedia/article/47-right-effective-remedy-and-fair-trial

Saad, L. (2016, February 26), Gallup vault: A Supreme Court power play. Retrieved from https://news.gallup.com/vault/189617/supreme-court-power-play.aspx

Santora, M. (2018). Amid growing uproar, Poland to remove 27 Supreme Court justices. New York Times.

Schlesinger, A., Jr. (2003a). The coming of the New Deal, 1933-1935 (The Age of Roosevelt, vol. 2). Boston, MA: Mariner Books.

Schlesinger, Arthur, Jr. (2003b). The politics of upheaval: 1935-1936 (The Age of Roosevelt, vol. 3). Boston, MA: Mariner Books.

Somin, I. (2017, November 27). The case against court-packing. The Volokh Conspiracy. Retrieved from https://www.washingtonpost.com/news/volokh-conspiracy/ $\mathrm{wp} / 2017 / 11 / 27 /$ the-case-against-court-packing/?utm_term=.59e6854f2696

Somin, I. (2018, July 3). The case against court-packing revisited. The Volokh Conspiracy. Retrieved from https://reason.com/volokh/2018/07/03/the-case-against-courtpacking-revisited?utm_source=feedburner\&utm_medium $=$ email

Sweeney, R. J. (2018). Constitution making in the Great Federations: The E.U. Constitution in light of U.S. constitutional crises. Mimeo: Claremont Graduate University.

Szczerbiak, A. (2017, January 19). Is Poland's constitutional tribunal crisis over?. University College London, The Constitution Unit. Retrieved from https://constitution-unit.com/2017/01/19/is-polands-constitutional-tribunal-crisis-over/

Szczerbiak, A. (2018, January 20). Analysis: Impact of Article 7 on Polish Politics. Delano. Retrieved from http://delano.lu/d/detail/news/analysis-impact-article7-polish-politics/167195

The Constitution of the Republic of Poland, chapter VIII, art. 175,178,179,183,187$190,194,195 \& 197$.

Tushnet, M. (2017, November 25). Expanding the judiciary, the Senate rules, and the small-c constitution. Balkinization. Retrieved from https://balkin.blogspot. com/2017/11/expanding-judiciary-senate-rules-and.html

U.S. Constitution. Impeachment of federal judges. Retrieved from https://ballotpedia. org/Impeachment_of_federal_judges

U.S. Constitution. The Bill of Rights \& All Amendments. Note 10. Retrieved from http:// constitutionus.com/\#n10

United States Senate Committee on Governmental Affairs \& House of Representatives Committee on Government Reform (published after each Presidential election). Plum book.

Wheeler, B. K. (1937, March 10). First Member of the Senate to back the President in '32. Chicago Forum. Retrieved from http://academic.brooklyn.cuny.edu/history/ johnson/wheeler.htm

White, E. G. (2000). The Constitution and the New Deal. Cambridge, MA: Harvard University Press.

Yoo, J. \& Delahunty, R. (2018, July 19). The foolish court-packing craze. National Review. Retrieved from https://www.nationalreview.com/2018/07/court-packing-ideas-threaten-judicial independence/?utm_source=Sailthru\&utm_ medium=email\&utm_campaign=NR\%20Daily\%20Monday\%20through\%20 Friday\%202018-07-19\&utm_term=NR5PM\%20Actives 